\title{
Evaluation of antimicrobial and antioxidant activities from Toona ciliata Roemer
}

\author{
Kumara Shanthamma Kavitha and Sreedharamurthy Satish ${ }^{*}$
}

\begin{abstract}
Background: In the present study, the different solvent extracts viz., petroleum ether, chloroform, ethyl acetate and methanol of the medicinal plant Toona ciliata (leaf and flower) were evaluated for phytochemical analysis, antimicrobial and antioxidant activities.

Methods: A qualitative phytochemical study was conducted to know the presence or absence of phytoconstituents in the test extracts. Antibacterial and antifungal activities were determined using disc diffusion assay against human and phytopathogens. MIC was carried out using Micro-broth dilution method for pathogenic bacteria and fungi. Radical scavenging activity was also studied using DPPH and ABTS method.

Results: The study revealed the presence of carbohydrates, proteins, phytosterols, flavonoids, glycosides, tannins and phenolic compounds. Ethyl acetate and methanol extracts showed moderate activity against test phytopathogenic bacteria compared to tetracycline. Moderate activity was found against Proteus mirabilis and least activity against Klebsiella pneumoniae, Salmonella typhi and Staphylococcus aureus with ethyl acetate and methanol extracts. Ethyl acetate and methanol extracts of Toona ciliata exhibited lowest MIC varied from 10-2.5 mgml-1 against test human pathogenic and phytopathogenic bacteria Significant antifungal activity against Microsporum canis was observed in methanol extract with an MIC of $1.25 \mathrm{mgml}^{-1}$ compared to miconozole. All the test extracts showed significant DPPH and ABTS radical scavenging activity in comparison with BHT.
\end{abstract}

Conclusions: The present study concludes that the plant Toona ciliata could be exploited for the isolation of bioactive compounds which could be a potential source for antimicrobials and antioxidants.

Keywords: Toona ciliata, Antioxidant activity, Antimicrobial activity, Phytochemical analysis

\section{Background}

Phytobiology perceives medicinal plants as a source of bioactive compounds which can be traced since evolution. The diverse living systems bear a rich biodiversity in nature. Since ancient era before scientific knowledge would evolve plants performed myriad functions on the biosphere. Among which use of plants in curing illness has been well documented. But it was after the advance technology and improved scientific knowledge transformed plants as source of therapeutic agents as they can serve the purpose with lesser side effects that are often associated with synthetic antimicrobials (Nagumanthri et al. 2012). It was estimated that current global market for plant-derived drugs is worth more than 20 billion and the market

\footnotetext{
* Correspondence: satish.micro@gmail.com

Department of Studies in Microbiology, Herbal Drug Technological,

Laboratory, University of Mysore, Manasagangotri, Mysore 570 006, Karnataka,
} India

continues growing (Lin et al. 2013). Perusal of literatures reports the medicinal properties of most of the plants bearing biological activity one such species is Toona ciliata (Meliaceae) which has been exploited for many traditional uses like construction purpose, dye preparation, furniture, medicines etc., (Negi et al. 2011). Toona ciliata along with Siderin, a compound isolated from petroleum ether extract showed significant antibacterial activity and also exhibited significant cytotoxicity (Chowdhury et al. 2003).

The plant extract also showed gastro protective activity (Malairajan et al. 2006). The inhibitive effects on formed protein non-enzymatic glycation an end product was studied from the ethanolic leaf extract (Shao-Hong 2010) Cedrelone, a tetra nortriterpenoid, isolated from Toona ciliata (Gopalakrishnan et al. 2000). Compounds such as 12-Deacetoxytoonacilin and $6 \alpha$-acetoxy-14 $\alpha, 15 \alpha-$ epoxyazadirone were isolated from the seeds (Neto et al. 
1995), 12- $\alpha$-Hydroxystigmast-4-en-3-one was isolated from the petroleum ether extract of Toona ciliata together with two steroids and three C-methyl coumarins (Chowdhury et al. 2002), norlimonoids and limonoids from the leaves and stems (Liao et al. 2007), three new norlimonoids (1-3), two new tirucallane-type triterpenoids ( 4 and 5), and a new pimaradiene-type diterpenoid (6), along with two known limonoids and eight known tirucallane-type triterpenoids, from the leaves and twigs (Chen et al. 2009), toonaciliatone, methyl-3 $\alpha$-acetoxy-1-oxomelic-14(15)-enate, perforin $\mathrm{A}$ and cholest-14-ene-3,7,24,25-tetrol-21,23-epoxy-21-methoxy4,4,8-trimethyl-3-(3-methyl-2-butenoate) from the leaves (Ning et al. 2010) and protolimonoids and norlimonoids from the stem bark of Toona ciliata (Wang et al. 2011). Although, several synthetic antioxidants and drugs are commercially available, natural products still substitute most of the chemical agents. In the present study, solvent extracts such as petroleum, chloroform, ethyl acetate and methanol of Toona ciliata were evaluated for the qualitative phyto-chemical analysis, in vitro antimicrobial and antioxidant activity which may lead to the finding of more effective agent for the management of diseases and effective potential source of natural antioxidant that may help in preventing various oxidative stresses.

\section{Methods}

\section{Preparation of the extract}

Plant material of Toona ciliata leaf and flower were washed with distilled water and shade dried. The dried leaves and flower were ground together to a fine powder using Waring blender. The coarsely powdered sample $(50 \mathrm{~g})$ was filled in the thimble and extracted successively with petroleum ether, chloroform, ethyl acetate and methanol using a Soxhlet extractor. The filtrate was evaporated to dryness under reduced pressure using rotary vacuum evaporator. The extracts were stored in ambient bottles until further use (Satish et al. 2007).

\section{Preliminary phytochemical screening}

The freshly prepared crude solvent extracts of Toona ciliata were qualitatively tested for the presence of phytochemical constituents such as alkaloids, flavones, terpenoids, phenols, tannins etc., by standard methods (Harborne 1973; Sofowara 1993; Ghani 2003).

\section{Bacterial strains}

Authenticated cultures of Gram positive bacteria such as Bacillus subtilis (MTCC 121), Listeria monocytogenes (MTCC 839), Staphylococcus aureus (MTCC 7443), Staphylococcus epidermidis (MTCC 435), Gram negative Escherichia coli (MTCC 7410), Enterobacter aerogenes (MTCC 7325), Klebsiella pneumoniae (MTCC 7407), Proteus mirabilis (MTCC 425), Pseudomonas aeruginosa (MTCC 7903), Salmonella typhimurium (MTCC 1254),
Vibrio parahaemolyticus (MTCC 451) and Erwinia carotovora (MTCC 1428) were procured from MTCC, Chandigarh, India. Authentic pure cultures of phytopathogens Xanthomonas axonopodis pv. malvacearum, Xanthomonas campestris pv. vesicatoria and Xanthomonas oryzae pv. oryzae were procured from DANIDA research laboratory, University of Mysore, India.

\section{Fungal strains}

Four plant fungi Aspergillus niger, Aspergillus flavus, Drechslera and Fusarium verticillioides and three human dermatophytic fungi Candida albicans, Microsporum canis and Microsporum gypsum were used.

\section{Preparation of inoculums}

Bacterial and fungal inoculums were prepared from $24 \mathrm{~h}$ old pure culture grown on nutrient agar for bacteria and a week old culture on potato dextrose agar for fungi. Bacterial colonies were pre-cultured in nutrient broth medium and kept overnight, then centrifuged at $10,000 \mathrm{rpm}$ for $5 \mathrm{~min}$. Pellet was suspended in sterilized distilled water and the cell turbidity was assessed spectroscopically in comparable to that of the $0.5 \mathrm{McF}$ arland standards (approximately $1.5 \times 10^{8} \mathrm{CFU} / \mathrm{ml}$ ) whereas, the fungal spores was scraped from the mother culture and dispensed in sterilized distilled water. Then the spore density was adjusted spectrophotometrically to obtain approximately $10^{5}$ spores $/ \mathrm{ml}$ final concentration. Then the inoculums were used for the antibacterial and antifungal assays (Mahesh et al. 2008).

\section{Antibacterial and antifungal activity}

Antibacterial and antifungal activity of Toona ciliata solvent extracts was determined using a modified Kirby Bauer disc diffusion method. Briefly, $100 \mu \mathrm{l}$ of the test bacteria/fungi was spread onto the nutrient agar and potato-dextrose agar plates respectively. The different test solvent extracts (petroleum ether, chloroform, ethyl acetate and methanol) were loaded to the sterilized sterile $6 \mathrm{~mm}$ discs, allowed to dry and then the impregnated discs with $50 \mu \mathrm{l}\left(100 \mathrm{mgml}^{-1}\right.$ concentration) onto the inoculated plates. The plates were allowed to stand at $4^{\circ} \mathrm{C}$ for $2 \mathrm{~h}$ before incubation with the test microbial agents. Bacterial plates were incubated at $37^{\circ} \mathrm{C}$ for $24 \mathrm{~h}$ and at room temperature for 3-4 days for fungi. The diameters of the inhibition zones were measured in $\mathrm{mm}$. All the assays were done in triplicate and the results were given in mean \pm SD. Standard antibiotics such as gentamicin and tetracycline for pathogenic bacteria, bavistin and miconozole for pathogenic fungi served as positive controls (Bauer et al. 1966). 
Table 1 Qualitative chemical analysis of test solvent extracts of Toona ciliata leaf and flower

\begin{tabular}{|c|c|c|c|c|c|c|}
\hline \multirow[t]{2}{*}{ SI no. } & \multirow[t]{2}{*}{ Tests } & \multicolumn{5}{|c|}{ Solvent extracts of Toona ciliata } \\
\hline & & Petroleum ether & Chloroform & Ethyl acetate & Methanol & Aqueous \\
\hline \multirow[t]{3}{*}{ I } & Carbohydrates test & & & & & \\
\hline & a) Molisch's test & + & + & + & + & + \\
\hline & b) Fehling's test & + & + & + & + & + \\
\hline \multirow[t]{6}{*}{ II } & Proteins \& Aminoacids & & & & & \\
\hline & a) Ninhydrin test & - & - & - & - & - \\
\hline & b) Biuret test & - & + & + & - & - \\
\hline & c) Sodium bicarbonate test & - & - & - & - & - \\
\hline & d) Tannic acid test & - & - & - & - & - \\
\hline & e) Xanthoprotein test & + & + & + & + & + \\
\hline \multirow[t]{4}{*}{ III } & Alkaloids & & & & & \\
\hline & a) Wagner's test & + & + & + & + & + \\
\hline & b) Dragendorff's test & + & + & + & + & + \\
\hline & c) Mayer's test & + & + & + & + & + \\
\hline \multirow[t]{2}{*}{ IV } & Saponins & & & & & \\
\hline & a) Foam test & - & - & - & - & + \\
\hline \multirow[t]{4}{*}{ v } & Flavonoids & & & & & \\
\hline & a) Ferric chloride test & - & - & + & + & + \\
\hline & b) Shinoda test & - & + & + & + & + \\
\hline & c) Alkali \& acid test & + & - & + & - & - \\
\hline \multirow[t]{6}{*}{ VI } & Tannins \& phenolic compounds & & & & & \\
\hline & a) Ferric chloride test & - & - & + & + & + \\
\hline & b) Heavy metals test & & & & & \\
\hline & i) Copper sulphate test & - & + & + & + & + \\
\hline & ii) Potassium ferricyanide test & - & + & + & - & + \\
\hline & iii) Nitric acid test & + & + & + & + & + \\
\hline \multirow[t]{2}{*}{ VII } & Glycosides & & & & & \\
\hline & a) Modified Borntrager's test & + & - & - & - & + \\
\hline \multirow[t]{8}{*}{ VIII } & Phytosterols & & & & & \\
\hline & a) Libermann- Burchard's test & + & + & + & + & + \\
\hline & b) Terpenoids & & & & & \\
\hline & i) 2,4-DNPH test & + & + & + & + & + \\
\hline & c) Anthraquinones & & & & & \\
\hline & i) Borntrager's test & + & + & + & + & + \\
\hline & d) Steroids & & & & & \\
\hline & i) Salkowski's test & + & + & + & + & + \\
\hline
\end{tabular}

\section{Microbroth dilution method}

Minimal inhibition concentration was determined by 2,3,5- triphenyl tetrazolium chloride (TTC) and (3-(4,5dimethylthiazol-2-yl)-2,5-diphenyltetrazolium bromide (MTT) assay using microtitre ELISA plate for bacteria and fungi respectively (Sette et al. 2006; Buatong et al. 2011). The 96 wells were filled with Muller-Hinton broth and Sabouraud's broth medium containing different concentration of solvent extracts, standard reference antibiotics such as gentamycin and miconozole against bacteria and dermatophytic fungi respectively. Antibacterial activity was detected by adding $0.5 \%$ TTC (Merck) aqueous solution and antifungal activity by adding $10 \mu \mathrm{l}$ of a (3-(4,5-dimethylthiazol-2-yl)-2,5-diphenyltetrazolium bromide (MTT) solution $\left[5 \mathrm{mgml}^{-1} \mathrm{MTT}\right.$ in phosphate buffered saline (PBS), $\mathrm{pH}$ 7.4]. MIC was 
Table 2 Antibacterial activity measured as zone of inhibition at $50 \mu \mathrm{l}(100 \mathrm{mg} / \mathrm{ml})$ of solvent extracts of Toona ciliata (leaf and flower) and standard antibiotics

\begin{tabular}{|c|c|c|c|c|c|c|}
\hline \multirow[t]{2}{*}{ SL no. } & \multirow{2}{*}{$\begin{array}{l}\text { Pathogenic bacteria } \\
\text { Human pathogens }\end{array}$} & \multicolumn{4}{|c|}{ Solvent extracts $(50 \mu \mathrm{l})$ zone of inhibition in $\mathrm{mm}(\mathrm{MIC}$ in $\mathrm{mg} / \mathrm{ml})$} & \multirow{2}{*}{$\begin{array}{l}\text { Antibiotics } \\
\text { Gentamicin }\end{array}$} \\
\hline & & Petroleum ether & Chloroform & Ethyl acetate & Methanol & \\
\hline \multirow[t]{2}{*}{1} & Bacillus subtilis & $0.00 \pm 0.00$ & $0.00 \pm 0.00$ & $0.00 \pm 0.00$ & $0.00 \pm 0.00$ & $34.66 \pm 0.57$ \\
\hline & & (ND) & (ND) & (ND) & (ND) & $(0.156)$ \\
\hline \multirow[t]{2}{*}{2} & Escherichia coli & $0.00 \pm 0.00$ & $0.00 \pm 0.00$ & $0.00 \pm 0.00$ & $0.00 \pm 0.00$ & $25.33 \pm 0.57$ \\
\hline & & (ND) & (ND) & (ND) & (ND) & $(0.625)$ \\
\hline \multirow[t]{2}{*}{3} & Klebsiella pneumoniae & $0.00 \pm 0.00$ & $0.00 \pm 0.00$ & $0.00 \pm 0.00$ & $9.00 \pm 0.00$ & $21.33 \pm 1.15$ \\
\hline & & (ND) & (ND) & (ND) & (5) & $(1.25)$ \\
\hline \multirow[t]{2}{*}{4} & Listeria monocytogenes & $0.00 \pm 0.00$ & $0.00 \pm 0.00$ & $0.00 \pm 0.00$ & $0.00 \pm 0.00$ & $25.00 \pm 1.00$ \\
\hline & & (ND) & (ND) & (ND) & (ND) & $(0.3125)$ \\
\hline \multirow[t]{2}{*}{5} & Pseudomonas aeruginosa & $0.00 \pm 0.00$ & $0.00 \pm 0.00$ & $0.00 \pm 0.00$ & $0.00 \pm 0.00$ & $25.00 \pm 1.00$ \\
\hline & & (ND) & (ND) & (ND) & (ND) & $(0.3125)$ \\
\hline \multirow[t]{2}{*}{6} & Proteus mirabilis & $0.00 \pm 0.00$ & $0.00 \pm 0.00$ & $20.66 \pm 0.57$ & $15.33 \pm 0.57$ & $30.66 \pm 0.57$ \\
\hline & & (ND) & (ND) & $(2.5)$ & $(2.5)$ & $(0.156)$ \\
\hline \multirow[t]{2}{*}{7} & Salmonella typhi & $0.00 \pm 0.00$ & $0.00 \pm 0.00$ & $10.00 \pm 0.00$ & $10.00 \pm 0.00$ & $30.00 \pm 0.00$ \\
\hline & & (ND) & (ND) & (5) & (5) & $(0.156)$ \\
\hline \multirow[t]{2}{*}{8} & Staphylococcus aureus & $0.00 \pm 0.00$ & $0.00 \pm 0.00$ & $0.00 \pm 0.00$ & $12.66 \pm 0.57$ & $24.00 \pm 1.00$ \\
\hline & & (ND) & (ND) & (ND) & (5) & $(0.625)$ \\
\hline \multirow[t]{2}{*}{9} & Staphylococcus epidermidis & $0.00 \pm 0.00$ & $0.00 \pm 0.00$ & $13.33 \pm 0.57$ & $14.00 \pm 0.00$ & $28.66 \pm 1.15$ \\
\hline & & (ND) & (ND) & (5) & (5) & $(0.156)$ \\
\hline \multirow[t]{3}{*}{10} & Vibrio parahaemolyticus & $0.00 \pm 0.00$ & $0.00 \pm 0.00$ & $0.00 \pm 0.00$ & $0.00 \pm 0.00$ & $25.33 \pm 0.57$ \\
\hline & & (ND) & (ND) & (ND) & (ND) & $(0.3125)$ \\
\hline & Plant pathogens & & & & & Tetracycline \\
\hline \multirow[t]{2}{*}{11} & Erwinia carotovora & $0.00 \pm 0.00$ & $0.00 \pm 0.00$ & $10.66 \pm 0.57$ & $11.66 \pm 0.57$ & $34.00 \pm 1.00$ \\
\hline & & (ND) & (ND) & (5) & (5) & $(0.156)$ \\
\hline \multirow[t]{2}{*}{12} & Xanthomonas axonopodis pv. malvacearum & $0.00 \pm 0.00$ & $0.00 \pm 0.00$ & $15.33 \pm 0.57$ & $13.66 \pm 0.57$ & $30.33 \pm 0.57$ \\
\hline & & (ND) & (ND) & (5) & (5) & $(0.156)$ \\
\hline \multirow[t]{2}{*}{13} & Xanthomonas oryzae pv. oryzae & $0.00 \pm 0.00$ & $0.00 \pm 0.00$ & $12.33 \pm 0.57$ & $8.33 \pm 0.57$ & $30.33 \pm 0.57$ \\
\hline & & (ND) & (ND) & (5) & (5) & $(0.156)$ \\
\hline \multirow[t]{2}{*}{14} & Xanthomonas campestris pv. vesicatoria & $0.00 \pm 0.00$ & $0.00 \pm 0.00$ & $10.66 \pm 0.57$ & $12.00 \pm 0.00$ & $31.00 \pm 0.00$ \\
\hline & & (ND) & (ND) & (5) & (5) & $(0.156)$ \\
\hline
\end{tabular}

Values are the mean of triplicates \pm SD $p<0.05$. ND Not Done.

defined as the lowest concentration of extract that inhibited visible growth, as indicated by the TTC and MTT staining (dead cells will not be stained).

\section{DPPH radical scavenging activity}

The antioxidant activity of Toona ciliata test solvent extracts was determined in terms of radical scavenging ability by DPPH method. Stock solution of $0.1 \mathrm{mM}$ $\mathrm{DPPH}$ in methanol was diluted using methanol. $1.0 \mathrm{ml}$ of solvent extracts solution of differing concentrations $\left(50-250 \mathrm{\mu gml}^{-1}\right)$ was added to $1.0 \mathrm{ml}$ of $\mathrm{DPPH}$ and made volume up to $3 \mathrm{ml}$. A negative control (reaction mixture without test extract) was also used in this test. The absorbance was measured at $517 \mathrm{~nm}$ after $30 \mathrm{~min}$. Inhibition was calculated by using the following equation:

$$
\% \text { inhibition }=\left[\mathbf{A}_{\text {control }}-\mathbf{A}_{\text {sample }} / \mathbf{A}_{\text {control }}\right] \times 100
$$

IC50 values were calculated as the concentration of each sample required to give $50 \%$ DPPH radical scavenging activity with respect to absorbance of blank from the graph. The results were compared with BHT. The experiment was performed in triplicates and values are expressed in \pm SD (Zhang et al. 2010). 
Table 3 Antifungal activity measured as zone of inhibition at $50 \mu \mathrm{l}(100 \mathrm{mg} / \mathrm{ml})$ of solvent extracts of Toona ciliata (leaf and flower) and standard antibiotics

\begin{tabular}{|c|c|c|c|c|c|c|}
\hline \multirow[t]{2}{*}{ SL no. } & \multirow{2}{*}{$\begin{array}{l}\text { Pathogenic fungi } \\
\text { Human pathogens }\end{array}$} & \multicolumn{4}{|c|}{ Solvent extracts $(50 \mu \mathrm{l})$ zone of inhibition in $\mathrm{mm}(\mathrm{MIC}$ in $\mathrm{mg} / \mathrm{ml})$} & \multirow{2}{*}{$\begin{array}{l}\text { Antibiotics } \\
\text { Miconozole }\end{array}$} \\
\hline & & Petroleum ether & Chloroform & Ethyl acetate & Methanol & \\
\hline \multirow[t]{2}{*}{1} & Candida albicans & $0.00 \pm 0.00$ & $0.00 \pm 0.00$ & $0.00 \pm 0.00$ & $0.00 \pm 0.00$ & $13.66 \pm 0.57$ \\
\hline & & (ND) & $(\mathrm{ND})$ & (ND) & (ND) & (ND) \\
\hline \multirow[t]{2}{*}{2} & Microsporum gypseum & $0.00 \pm 0.00$ & $0.00 \pm 0.00$ & $0.00 \pm 0.00$ & $0.00 \pm 0.00$ & $18.66 \pm 0.57$ \\
\hline & & (ND) & (ND) & (ND) & (ND) & (ND) \\
\hline \multirow[t]{3}{*}{3} & Microsporum canis & $0.00 \pm 0.00$ & $0.00 \pm 0.00$ & $0.00 \pm 0.00$ & $16.66 \pm 0.57$ & $18.00 \pm 0.00$ \\
\hline & & (ND) & (ND) & (ND) & (1.25) & $(1.25)$ \\
\hline & Plant pathogens & & & & & Bavistin \\
\hline \multirow[t]{2}{*}{4} & Aspergillus niger & $0.00 \pm 0.00$ & $0.00 \pm 0.00$ & $0.00 \pm 0.00$ & $0.00 \pm 0.00$ & $18.00 \pm 0.00$ \\
\hline & & (ND) & (ND) & (ND) & (ND) & (ND) \\
\hline \multirow[t]{2}{*}{5} & Aspergillus flavus & $0.00 \pm 0.00$ & $0.00 \pm 0.00$ & $0.00 \pm 0.00$ & $0.00 \pm 0.00$ & $17.66 \pm 0.57$ \\
\hline & & (ND) & (ND) & (ND) & (ND) & (ND) \\
\hline \multirow[t]{2}{*}{6} & Drechslera & $0.00 \pm 0.00$ & $0.00 \pm 0.00$ & $0.00 \pm 0.00$ & $0.00 \pm 0.00$ & $15.00 \pm 0.00$ \\
\hline & & (ND) & (ND) & (ND) & (ND) & (ND) \\
\hline \multirow[t]{2}{*}{7} & Fusarium verticillioides & $0.00 \pm 0.00$ & $0.00 \pm 0.00$ & $0.00 \pm 0.00$ & $0.00 \pm 0.00$ & $14.66 \pm 0.57$ \\
\hline & & (ND) & (ND) & (ND) & (ND) & $(\mathrm{ND})$ \\
\hline
\end{tabular}

Values are the mean of triplicates \pm SD $p<0.05$.

ND Not Done.

\section{ABTS assay}

The antioxidant activity of Toona ciliata test solvent extracts was determined for radical scavenging ability by ABTS method (Adedapo et al. 2009). The stock solution was prepared by using $7 \mathrm{mM}$ ABTS solution and 2.4 mM potassium per sulfate solution separately. The working solution was made by mixing the two stock solutions in equal quantities and allowed them to react for $12 \mathrm{~h}$. at room temperature in dark condition. $1.0 \mathrm{ml}$ of Toona ciliata test solvent extracts of differing concentrations (50-250 $\mathrm{gmml}^{-1}$ was added to $1.0 \mathrm{ml}$ of ABTS solution and diluted with methanol. The absorbance was taken at
$734 \mathrm{~nm}$ after $7 \mathrm{~min}$ using the spectrophotometer. The ABTS scavenging capacity of the extract was compared with that of $\mathrm{BHT}$ and percentage inhibition calculated as

ABTS radical scavenging activity $(\%)=$

$$
\left[\left(\mathbf{A}_{\text {control }} \mathbf{A}_{\text {sample }}\right)\right] /\left[\left(\mathbf{A}_{\text {control }}\right)\right] \times \mathbf{1 0 0}
$$

Where, $\mathrm{A}_{\text {control }}$ is the absorbance of ABTS radical + methanol; $\mathrm{A}_{\text {sample }}$ is the absorbance of ABTS radical + sample extract/standard. The experiment was performed in triplicates and values are expressed in \pm SD.

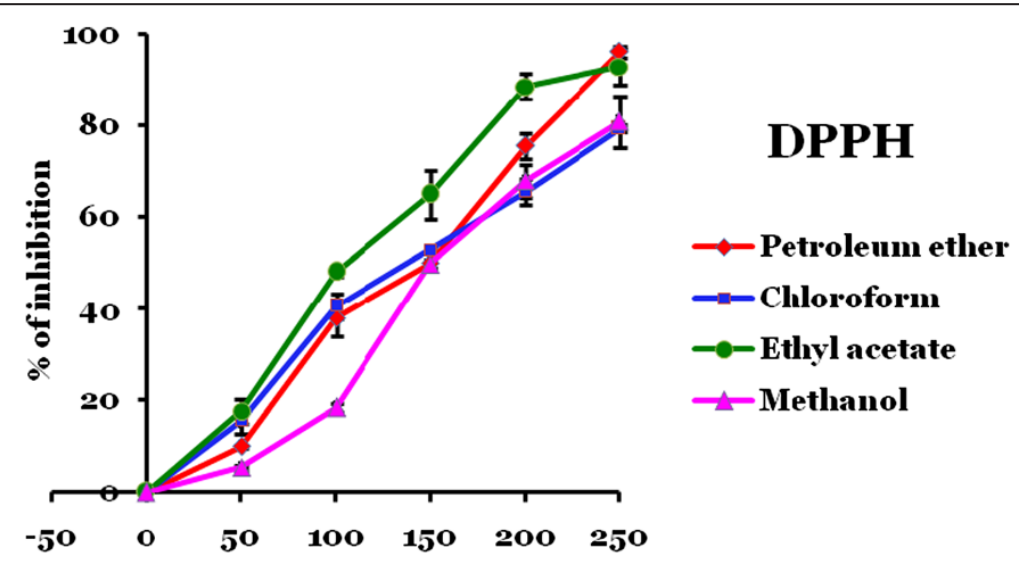

Concentration in $\mu^{\prime g m l}{ }^{-1}$

Figure 1 DPPH scavenging activity of test solvent extracts of Toona ciliata. Data expressed at $p<0.05$. 


\section{Results and discussion}

In the present study, preliminary chemical analysis of Toona ciliata leaf and flower extracts of different solvent extracts viz. petroleum ether, chloroform, ethyl acetate, methanol and water revealed the presence of carbohydrates, proteins, alkaloids and phytosterols (Table 1). Saponins was absent in all the extracts whereas flavonoids, tannins and phenolic compounds were found to be present in ethyl acetate and methanol extracts and glycosides was present in petroleum ether and aqueous extracts. Tables 2 and 3 shows the antibacterial and antifungal activities of test solvent extracts of Toona ciliata at $50 \mu \mathrm{l}\left(100 \mathrm{mgml}^{-1}\right)$ concentrations against human and phytopathogenic bacteria and fungi. Ethyl acetate extract showed moderate antibacterial activity against Proteus mirabilis and least activity against Salmonella typhi and Staphylococcus epidermis. Similarly, methanol extract also showed moderate antibacterial activity against Proteus mirabilis and least activity against Klebsiella pneumoniae, Salmonella typhi, Staphylococcus aureus and Staphylococcus epidermidis, whereas other test bacteria did not show any inhibition zone. Antibacterial activity against human and phytopathogenic bacteria was not observed with petroleum ether and chloroform extracts. Ethyl acetate and methanol extracts exhibited moderate activity against Xanthomonas axonopodis pv. malvacearum and least activity against Xanthomonas campestris pv. vesicatoria, Xanthomonas oryzae pv. oryzae and Erwinia carotovora in comparison with the standard tetracycline. Petroleum ether, chloroform and ethyl acetate solvent extracts did not exhibited any zone of inhibition against Aspergillus niger, Aspergillus flavus, Drechslera, Fusarium verticillioides, Candida albicans and Microsporum gypsum whereas, methanol extract showed significant activity only against Microsporum canis compared to the standard miconozole. Ethyl acetate and methanol extracts of Toona ciliata exhibited lowest MIC varied from 10-2.5 mgml ${ }^{-1}$ against Proteus mirabilis, Salmonella typhi, Staphylococcus epidermidis, Erwinia carotovora, Xanthomonas campestris pv. vesicatoria, Xanthomonas oryzae pv. oryzae and Xanthomonas axonopodis pv. malvacearum wherein, standard antibiotics gentamicin and tetracycline showed MIC ranging between 0.625-0.156 mgml ${ }^{-1}$ and $0.156 \mathrm{mgml}^{-1}$ against human pathogenic and phytopathogenic bacteria respectively. Methanolic extract of Toona ciliata showed MIC of $1.25 \mathrm{mgml}^{-1}$ against Microsporum canis.

Antioxidant activity using DPPH and ABTS method is illustrated in the Figures 1 and 2. The test solvent extracts viz., petroleum ether, chloroform, ethyl acetate and methanol exhibited significant free radical scavenging activity wherein, as the concentration increases the percentage inhibition of free radical also increases. Petroleum ether, chloroform, ethyl acetate and methanol extracts of Toona ciliata showed DPPH significant activity with $\mathrm{IC}_{50}$ value of 150, 135.5, 105 and $92.5 \mathrm{\mu gml}^{-1}$ whereas ABTS scavenging activity showed $\mathrm{IC}_{50}$ value of about $145,120,120.5$ and $95 \mu^{\mathrm{gml}^{-1}}$ respectively. Standard BHT showed significant $\mathrm{DPPH}$ and ABTS scavenging activity with $\mathrm{IC}_{50}$ value of

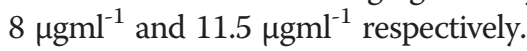

In the present study, methanol extract of Toona ciliata revealed the presence of carbohydrates, alkaloids, flavonoids, phytosterols, tannins and phenolic compounds which justifies the earlier findings of Gautam et al. (2010). Scientific literatures perused by far suggest antimicrobial activity against human pathogens whereas no reports confer the evaluation of Toona ciliata against phytopathogens which has been reported in the present investigation with ethyl acetate and methanol extracts of Toona ciliata against Erwinia carotovora, Xanthomonas axonopodis pv. malvacearum, Xanthomonas campestris pv. vesicatoria and Xanthomonas oryzae pv. oryzae along

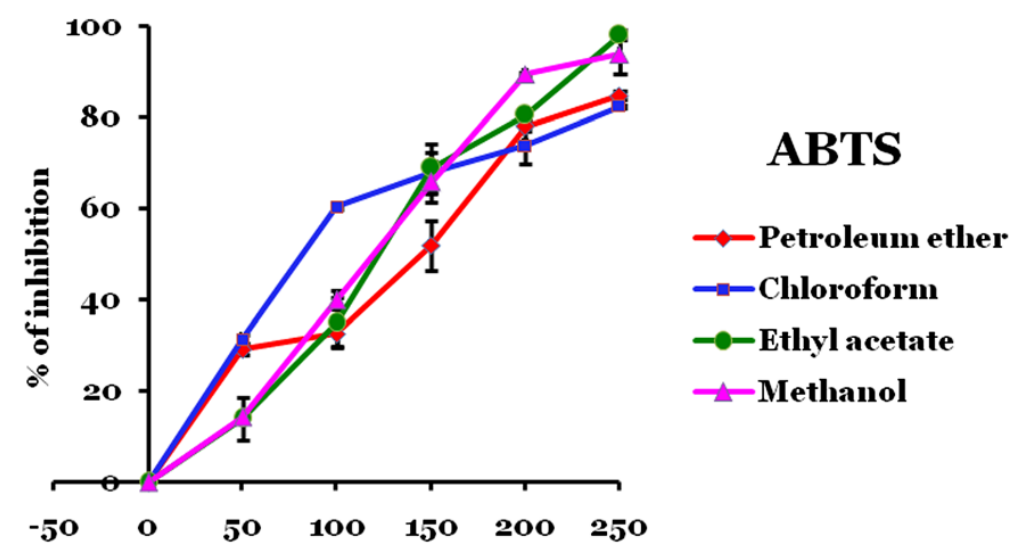

Concentration in $\mu^{\prime g m l}{ }^{-1}$

Figure 2 ABTS scavenging activity of test solvent extracts of Toona ciliata. Data expressed at $p<0.05$. 
human pathogen viz Salmonella typhi, Staphylococcus epidermis and Klebsiella pneumoniae suggests its antimicrobial potential which has also been studied previously against various pathogenic bacteria (Bibi et al. 2011; Kiladi 2012). Crude extracts upon evaluation of antioxidant activity using $\mathrm{DPPH}$ and $\mathrm{ABTS}$ method showed $\mathrm{IC}_{50}$ value

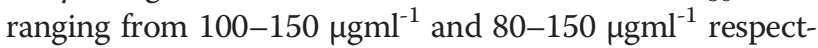
ively with different test solvent extracts. Earlier report of antioxidant compound has been well described with potent DPPH activity resulting $\mathrm{IC}_{50}$ value $1.02 \mu \mathrm{gml}^{-1}$ (Ekaprasada et al. 2009).

\section{Conclusions}

The present investigation concludes that methanol extract of Toona ciliata exhibited maximum inhibition against test human and phytopathogens. Crude extracts displayed significant antioxidant activity, thus results obtained in the present investigation are promising enough for further isolation and characterization to reveal any novel metabolite of pharmaceutical importance.

\section{Competing interests}

Both authors declare that they have no competing interests.

\section{Authors' contributions}

KSK design the experiment, carried out the experiment, and contributed in framing the article. SS supervised the work. Both authors read and approved the final manuscript.

\section{Acknowledgments}

The authors are thankful to the University of Grant Commission (UGC) RGNFs, Govt. of India for providing financial support and the Department of Studies in Microbiology, University of Mysore, Manasagangotri, Mysore.

Received: 24 August 2013 Accepted: 12 December 2013

Published: 31 Dec 2013

\section{References}

Adedapo AA, Jimoh FO, Koduru S, Masika PJ, Afolayan AJ (2009) Assessment of the medicinal potentials of the methanol extracts of the leaves and stems of Buddleja saligna. BMC Complem Altern Med 9:21, doi:10.1186/1472-6882-9-21

Bauer AW, Kirby WMM, Sherries SC, Tunk M (1966) Antibiotic susceptibility of testing by a standard single disc method. Amer I Clin Pathol 36:492-496

Bibi Y, Nisa S, Chaudhary MF, Zia M (2011) Antibacterial activity of some selected medicinal plants of Pakistan. BMC Complem Altern Med 11:52, doi:10.1186/1472-6882-11-52

Buatong J, Phongpaichit S, Rukachaisirikul V, Sakayaroj J (2011) Antimicrobial of crude extracts from mangrove fungal endophytes. World J Microbiol Biotechnol 27(12):3005-3008

Chen HD, Yang SP, Wu Y, Dong L, Yue JM (2009) Terpenoids from Toona ciliata. J Nat Prod 72(4):685-689

Chowdhury R, Rashid RB, Hasan CM (2002) Steroids and C-methyl coumarins from Toona ciliata. J Bang Acad Sci 26:219-222

Chowdhury R, Hasan CM, Rashid MA (2003) Antimicrobial activity of Toona ciliata and Amoora rohituka. Fitoterapia 74(1-2):155-158

Ekaprasada TM, Nurdin H, Ibrahim S, Dachriyanus (2009) Antioxidant activity of methyl gallate isolated from the leaves of Toona sureni. Indo J Chem 9(3):457-460

Gautam AD, Ahirwar DJ, Sujane M, Sharma GN (2010) Pharmacognostic evaluation of Toona ciliata bark. J Adv Pharm Technol Res 1(2):216-220

Ghani A (2003) Medicinal plants of Bangladesh, 2nd edn. The Asiatic society of Bangladesh, Dhaka, p 603

Gopalakrishnan G, Singh NDP, Kasinath V, Malathi R, Rajan SS (2000) Photo oxidation of cedrelone, a tetranortriterpenoid from Toona ciliata. Photochem Photobiol 72:464-466
Harborne JB (1973) Phytochemical methods a guide to modern techniques of plant analysis. Chapman and Hall, London, p 49e188

Kiladi CP (2012) Evaluation of antibacterial potential of Toona ciliata Roemer against ten different pathogenic bacteria. Int I Univ Pharm Life Sci 2(3):2249-6793

Liao SG, Yang SP, Yuan T, Zhang CR, Chen HD, Wu Y, Xu YK, Yue JM (2007) Limonoids from the leaves and stems of Toona ciliata. J Nat Prod 70:1268-1273

Lin Y, Wang C, Chen I, Jheng J, Li J, Tung C (2013) TIPdb: A database of anticancer, antiplatelet, and antituberculosis phytochemicals from indigenous plants in Taiwan. ScientificWorld J, doi:10.1155/2013/736386

Mahesh B, Satish S (2008) Antimicrobial activity of some important medicinal plant against plant and human pathogens. World J Agricult Sci 4:839-843

Malairajan P, Gopalakrishnan G, Narasimhan S, Jessi KVK (2006) Analgesic activity of some Indian medicinal plants. J Ethnopharmacol 106:425-428

Nagumanthri V, Rahiman S, Tantry BA, Nissankararao P, Phani kumar M (2012) In vitro antimicrobial activity of Acacia nilotica, Ziziphus mauritiana, Bauhinia variegate and Lantana camara against some clinical isolated strains. Iran J Sci Technol A2:213-217

Negi SJ, Bisht VK, Bhandari KA, Bharti MK, Sundriyal RC (2011) Chemical and pharmacological aspects of Toona(Meliaceae). Res J Phytochem 5:14-21

Neto JO, Agostinho SMM, Silva DMF, Vieira PC, Fernandes JB, Pinheiro AL, Vilela EF (1995) Limonoids from seeds of Toona ciliata and their chemosystematic significance. Phytochemistry 38:397-401

Ning J, He HP, Li SF, Geng ZL, Fang X (2010) Triterpenoids from leaves of Toona ciliata. J Asian Natl Prod Res 12:448-452

Satish S, Mohana DC, Ranhavendra MP, Raveesha KA (2007) Antifungal activity of some plant extracts against important seed borne pathogens of Aspergillus sp. J Agricult Technol 3:109-119

Sette LD, Passarini MRZ, Delarmelina C, Salati F, Duarte MCT (2006) Molecular characterization and antimicrobial activity of endophytic fungi from coffee plants. World J Microbiol Biotechnol 22:1185-1195

Shaohong C, Pengkang R, Yuntao Z (2010) Inhibitory effects of ethanol extract from Toona sinensis leaves on the formation of protein non-enzymatic. J Anhui Agricult Sci 11:5642

Sofowara A (1993) Medicinal plants and traditional medicine in Africa. Spectrum Book Ltd, Ibadan, Nigeria, p 289

Wang J, Liu H, Kurt'an T, M'andi A, S'andor A, Jia L, Zhang H, Guo Y (2011) Protolimonoids and norlimonoids from the stem bark of Toona ciliata var. pubescens. Org Biomol Chem 9(22):7685-7696

Zhang L, Gao Y, Zhang Y, Liu J, Yu J (2010) Change in bioactive compounds and antioxidant activities in pomegranate leaves. Sci Hortic 123:543-546

\subsection{6/2093-3371-4-23}

Cite this article as: Kavitha and Satish: Evaluation of antimicrobial and antioxidant activities from Toona ciliata Roemer. Journal of Analytical Science and Technology 2013, 4:23

\section{Submit your manuscript to a SpringerOpen ${ }^{\odot}$ journal and benefit from:}

- Convenient online submission

Rigorous peer review

- Immediate publication on acceptance

- Open access: articles freely available online

- High visibility within the field

- Retaining the copyright to your article

Submit your next manuscript at $>$ springeropen.com 